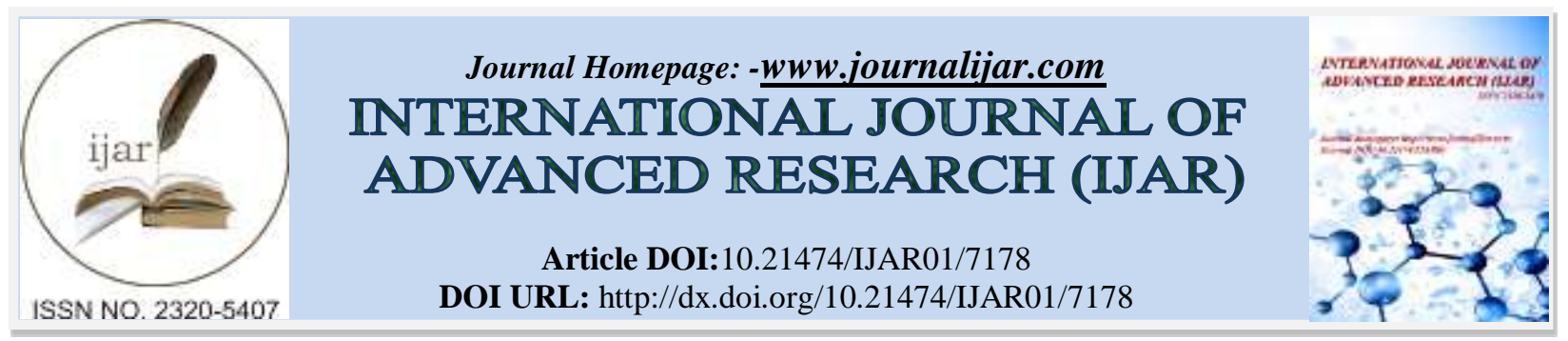

RESEARCH ARTICLE

\title{
COMPARISON OF PHENOTYPIC AND GENOTYPIC METHODS FOR DETECTION OF CARBAPENEM RESISTANCE IN AN INDIAN TERTIARY CARE HOSPITAL.
}

\author{
Asifa Bhat ${ }^{1}$, Dalip K. Kakru ${ }^{1}$, Suhail Farooq ${ }^{2}$, Dekyong Angmo ${ }^{1}$, Mohmmad Suhail ${ }^{3}$, Shaista Nazir ${ }^{1}$, Shazia \\ Benazir $^{1}$ and Lenah Bashir ${ }^{1}$.
}

Manuscript Info

Abstract

Manuscript History

Received: 23 March 2018

Final Accepted: 25 April 2018

Published: May 2018

Copy Right, IJAR, 2018,. All rights reserved.

\section{Introduction:-}

Carbapenem-resistant Enterobacteriaceae (CRE), an emerging threat to public health, belong to a family of microorganisms that are difficult to treat because they are highly resistant to antibiotics. These bacteria can cause serious hospital- and community-acquired infections, such as bloodstream infections, wound infections, urinary tract infections and pneumonia. ${ }^{[1]}$

Unlike Methicillin Resistant Staphylococcus aureus (MRSA) resistance, which is mediated by a single mechanism in a single bacterial species, the mechanisms of carbapenem resistance are complex because they involve a broad range of organisms and are mediated by different mechanisms, such as the production of $\beta$-lactamases,efflux pump and porin mutations. ${ }^{[2]}$

Carbapenemases are $\beta$-lactamases with versatile hydrolytic capacities. They hydrolyze penicillins, cephalosporins, monobactams, and carbapenems. Bacteria producing these $\beta$-lactamases may cause serious infections in which the carbapenemase activity renders many $\beta$-lactams ineffective. Carbapenemases are members of the Ambler class A, B, and D $\beta$-lactamases. The class A carbapenemase group includes members of the SME, IMI, NMC, GES, and KPC families. Of these, the KPC carbapenemases are the most prevalent,found mostly on plasmids in Klebsiella pneumoniae. ${ }^{[3]}$ The first member of the KPC family was discovered through the ICARE surveillance project in a $K$. pneumoniae clinical isolate from North Carolina in $1996 .{ }^{[4]}$

The gene encoding the KPC enzyme is usually flanked by transposon-related sequences and has been identified on conjugative plasmids, therefore,potential for dissemination is significant. ${ }^{[5,6,7]}$ Isolates that acquire this enzyme are usually resistant to several other classes of antimicrobial agents used as treatment options. Laboratory identification of KPC-producing clinical isolates will be critical for limiting the spread of this resistance mechanism. ${ }^{[8]}$

The most commonly used method for detection of CRE is the measurement of minimum inhibitory concentration (MIC). MICs are important in diagnostic laboratories to confirm resistance of microorganisms to an antimicrobial agent . It is a quantitative measurement of antibiotic activity, and it is defined as the minimum concentration of an antibiotic that can inhibit visible microbial growth under normal conditions. ${ }^{[9,10]}$ In 2009, CLSI published a recommendation that carbapenem susceptible Enterobacteriaceae with susceptible, but elevated MIC, be tested for the presence of the carbapenemase enzyme using the Modified Hodge Test (MHT). ${ }^{[11]}$ In 2010, the CLSI changed 
the carbapenem resistance criteria to ensure that KPC-producing organisms were not misclassified. This change eliminated the need for secondary testing by MHT. So, a lower MIC for antibiotic resistance was established for CREs and these criteria were again revised in 2012. ${ }^{[12]}$ Polymerase chain reaction confirms the detection of a particular gene.So the present study was conducted to compare MIC with blakpc gene detection in meropenem resistant Klebsiella pneumoniae isolates.

\section{Material and methods:-}

\section{Study design:-}

This study was conducted in the Department of Microbiology, Sher-i-Kashmir Institute of Medical Sciences, Srinagar; over a period of one year and three months.

\section{Methodology:-}

The study included all isolates of Klebsiella pneumoniae recovered from blood culture of the patients. The identification and antimicrobial susceptibility of the isolates was done on Vitek 2. Isolates that are resistant to Meropenem were included for phenotypic(MIC) and genotypic(PCR) testing of KPC. MIC was determined by broth microdilution for meropenem. ${ }^{[13]}$ These isolates were then tested for blaKPC gene by conventional polymerase chain reaction. ${ }^{[14]}$

\section{MIC was done by Broth Microdilution method as under:-} Preparation of antibiotic stock solution for Meropenem:Stock solution was prepared using the formula:-

\section{0/P x V x C = W}

Where, $\mathrm{P}=$ potency given by manufacturer $(\mu \mathrm{g} / \mathrm{mg}), \mathrm{V}=$ volume required $(\mathrm{ml}), \mathrm{C}=$ final concentration of solution $(\mathrm{mg} / \mathrm{L})$ and $\mathrm{W}=$ weight of antibiotic $(\mathrm{mg})$ to be dissolved in volume $\mathrm{V}(\mathrm{ml})$.

The stock solution was prepared in such a way that its concentration was $1 \mathrm{mg} / \mathrm{ml}$ or greater .Meropenem stock solution was prepared by dissolving $55.43 \mathrm{mg}$ of the antibiotic powder in $1 \mathrm{ml}$ of distilled water.

\section{Preparation of working antibiotic solution:-}

Working solution was prepared as per the formula $\mathrm{V} 1 \mathrm{C} 1=\mathrm{V} 2 \mathrm{C} 2(\mathrm{~V} 1=$ volume of starting solution needed,C1concentration of starting solution needed, $\mathrm{C} 2=$ final concentration of new solution, $\mathrm{V} 2=$ final volume of new solution).The working solution was prepared one concentration higher than the highest concentration of the drug being tested.Thus for meropenem, $256 \mu \mathrm{g} / \mathrm{ml}$ of working solution was prepared by dissolving $51.2 \mu \mathrm{l}$ of stock solution in Muller-Hinton broth.

\section{Microbroth dilution method:-}

Using a micropipette $50 \mu \mathrm{l}$ of Muller Hinton broth was dispensed into all wells of a microtitre plate leaving the first column unfilled.After this $100 \mu \mathrm{l}$ of working antibiotic solution (concentration $256 \mu \mathrm{g} / \mathrm{ml}$ ) was added to the wells of the first column.From the first well $50 \mu \mathrm{l}$ of the working antibiotic solution was pipetted out and added to the second well,already containing $50 \mu \mathrm{l}$ of $\mathrm{MH}$ broth. From the second well $50 \mu \mathrm{l}$ of solution was added into the next well and so on and so forth till the well well number 10 was reached from which $50 \mu 1$ of solution was discarded .The final concentration in the wells ranged from $256-0.5 \mu \mathrm{g} / \mathrm{ml}$. The last two columns served as growth control and sterility control respectively.

The turbidity of the bacterial inoculum was adjusted to $0.5 \mathrm{McFarland}$ standards and $50 \mu \mathrm{l}$ of it was dispensed into all the wells of microtitre plate.Finally the plates were incubated at $37^{\circ} \mathrm{C}$ overnight and read the other day.

Results were recorded by visual inspection of the microtitre plates after overnight incubation at $37^{\circ} \mathrm{C}$ as per CLSI guidelines. The test was considered valid when acceptable growth (more or equal to $2 \mathrm{~mm}$ button or definite turbidity ) was seen in the positive control well.Absence of turbidity or a button of less than $2 \mathrm{~mm}$ diameter in the test well was thus taken as the MIC of the organism under test . 


\section{Polymerase chain reaction:-}

DNA Extraction: Molecular identification of KPC-producing Klebsiella pneumoniae was performed by blaKPC PCR using bacterial lysates from overnight broths prepared by removal of $200 \mu \mathrm{l}$ of broth culture, centrifugation $(12,000 \times g ; 2 \mathrm{~min})$, resuspension in $200 \mu \mathrm{l}$ of molecular-grade water, boiling at $95^{\circ} \mathrm{C}$ for $10 \mathrm{~min}$, and discarding the cellular debris by centrifugation $\left(12,000 \times g ; 2\right.$ min at $\left.4^{\circ} \mathrm{C}\right)$.PCR analysis for bla KPC was performed with $1 \mu$ of cell lysates, using the following primers designed to identify all blaKPC genes $\left(\right.$ bla $a_{\mathrm{KPC}-1}$ through $\left.b l a_{\mathrm{KPC}-7}\right)$ : KPC forward (ATGTCACTGTATCGCCGTCT). KPC reverse (TTTTCAGAGCCTTACTGCCC). The Reaction was set up in a PCR vial, after adding the master mix, the forward and reverse primers and the extracted DNA. $25 \mu 1$ of Master Mix contained 10X Taq buffer, 2mM Mgcl2, $0.4 \mathrm{mM}$ dNTPs mix, and 2U Proofreading Taq DNA polymerase. (Thermo SCIENTIFIC ,USA) Lysates derived from Escherichia coli ATCC 25922 and blaKPC carrying $K$. pneumoniae strain 1705 were used as negative and positive controls,respectively, in each PCR. The PCR conditions were as follows: $15 \mathrm{~min}$ at $95^{\circ} \mathrm{C}$ and 38 cycles of $1 \mathrm{~min}$ at $94^{\circ} \mathrm{C}, 1 \mathrm{~min}$ at $62^{\circ} \mathrm{C}$, and $1 \mathrm{~min}$ at $72^{\circ} \mathrm{C}$, followed by an extension step of $10 \mathrm{~min}$ at $72^{\circ} \mathrm{C}$. The PCR products were subjected to electrophoresis on $2 \%$ agarose gel stained with ehidium bromide and visualized with UV light. The blaKPC gene gave band at 893bp

\section{Results:-}

Out of the total isolates 55(78.5\%) were meropenem resistant and 15(21.5\%) were meropenem sensitive. Fig.1

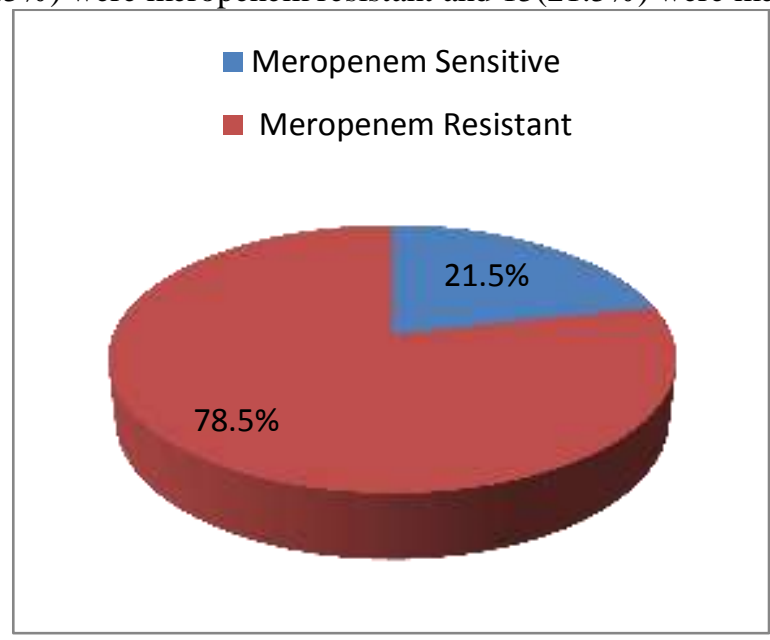

Fig.1:-Overall distribution of Klebsiella pneumoniae isolates (sensitive and resistant).

Minimum Inhibitory Concentration (MIC) was done on Meropenem resistant isolates by Broth microdilution test. For (36.3\%) isolates MIC was $\geq 256 \mu \mathrm{g} / \mathrm{ml}$ followed by $128 \mu \mathrm{g} / \mathrm{ml}$ in $(32.7 \%)$ isolates followed by 64 in $(20 \%)$ isolates and 32 in (10.9\%). Fig 2

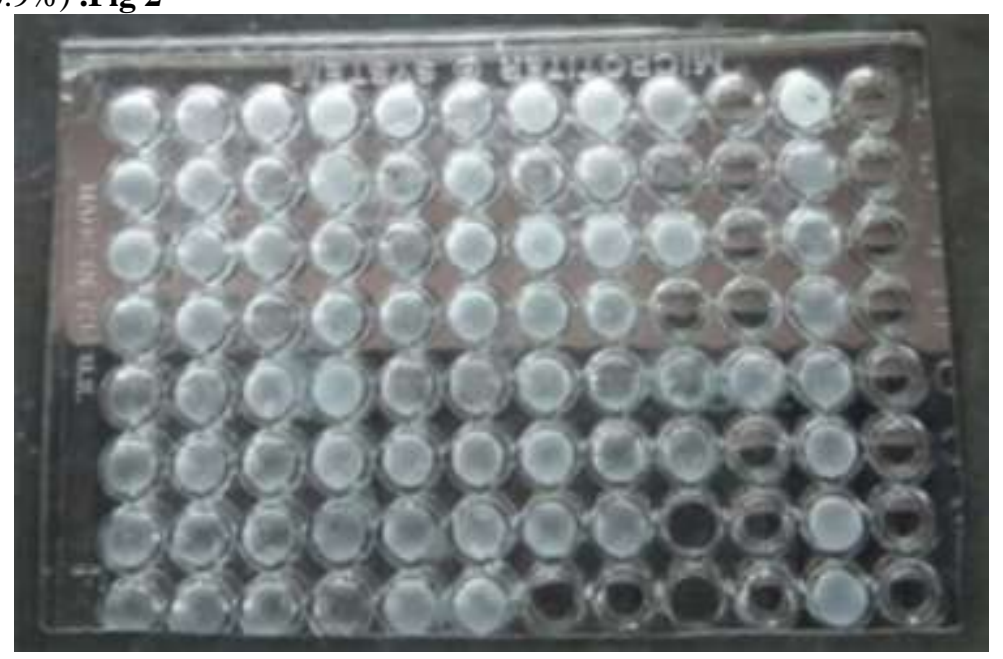

Fig.2:-Minimum Inhibitory Concentration (MIC) of meropenem for Klebsiella pneumoniae isolates by Broth Microdilution. 
On comparison of MIC with PCR for blaKPC gene findings it was seen that out of 20 isolates with MIC $\geq 256$, $18(90 \%)$ were positive for blaKPC gene, among isolates with MIC $128 \mu \mathrm{g} / \mathrm{ml}, 61 \%$ were positive for blaKPC gene . whereas isolates with MIC $64 \mu \mathrm{g} / \mathrm{ml}, 72.7 \%$ were positive for this gene and isolates with $\mathrm{MIC} 32 \mu \mathrm{g} / \mathrm{ml}, 66.7 \%$ were positive for the blaKPC gene.Table-1,Fig.3

Table-1:-MIC(meropenem) of blaKPC positive and negative Klebsiella pneumoniae isolates.

\begin{tabular}{|l|l|l|l|l|l|}
\hline MIC & \multicolumn{1}{|l|}{ TOTAL } & \multicolumn{1}{l|}{ PCR POSITIVE } & PCR NEGATIVE \\
\hline 32 & $6(10.9)$ & & $4(66.7)$ & $2(33.3)$ \\
\hline 64 & $11(20)$ & & $8(72.7)$ & $3(27.3)$ \\
\hline 128 & $18(32.7)$ & & $11(61.1)$ & $7(38.9)$ \\
\hline$\geq 256$ & $20(36.3)$ & & $18(90)$ & $2(10)$ \\
\hline
\end{tabular}

Chi square $6.56, \mathrm{p}$ value 0.087

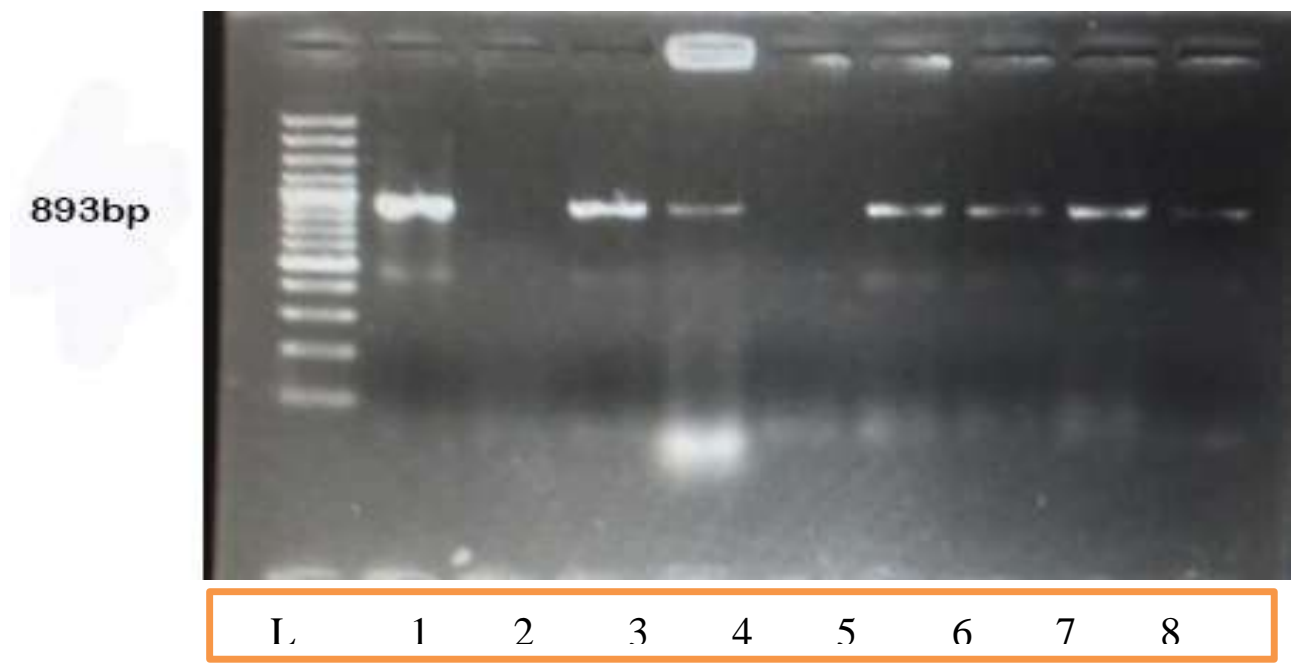

Fig. 3:-Poiymerase Chain Reaction(PCR) for blaKPC gene: Lane-L 100 bp DNA ladder, Lane-1, Positive Control; Lane-2, Negative Control; Lanes 3-9, Test strains

\section{Discussion:-}

Out of the total isolates 55(78.5\%) were meropenem resistant and 15(21.5\%) were meropenem sensitive .our study results are similar with study conducted by Marquez $\mathrm{P}$ et al according to which $83 \%$ isolates were carbapenem resistant Klebsiella pneumonia. ${ }^{[15]}$ According to a study conducted by Shanmugam P et al.(2013), Forty three $(93.4 \%)$ out of the 46 isolates were resistant to Meropenem. ${ }^{[16]}$ Seibert et al in their study in Brazil found $K$. pneumoniae was the microorganism that presented with the greatest resistance to carbapenems $(62.0 \%) .{ }^{[17]}$ Praveen et al., 2010 studied K. pneumoniae, from 134 clinical isolates about $43.6 \%$ percent isolates were resistant to Meropesnem. (Praveen et al., 2010). ${ }^{[18]}$

On comparison of MIC with PCR for blaKPC gene findings it was seen that out of 20 isolates with MIC $\geq 256$, $18(90 \%)$ were positive for blaKPC gene, among isolates with MIC $128 \mu \mathrm{g} / \mathrm{ml}, 61 \%$ were positive for blaKPC gene . whereas isolates with MIC $64 \mu \mathrm{g} / \mathrm{ml}, 72.7 \%$ were positive for this gene and isolates with $\mathrm{MIC} 32 \mu \mathrm{g} / \mathrm{ml}, 66.7 \%$ were positive for the blaKPC gene. According to a study conducted by Giani et al Carbapenem MICs of the 234 carbapenem-nonsusceptible $K$. pneumoniae, MIC of $>32 \mu \mathrm{g} / \mathrm{ml}$ was found in $94 \%$ isolates with ( KPC) carbapenemase, whereas isolates with (VIM) carbapenemase ,MIC range was 2 to $>32$, and those with (OXA) type carbapenemase MIC was 1 to $8 \mu \mathrm{g} / \mathrm{ml}$. ${ }^{[19]}$ Also according to Parveen et al. $43.6 \%$ were resistant to meropenem. The MIC of meropenem showed a varied range. Eight isolates showed a maximum MICs of $>128 \mu \mathrm{g} / \mathrm{mL}$, nine were MIC at $128 \mu \mathrm{g} / \mathrm{mL}$. Similarly 6 isolates showed MIC of $16 \mu \mathrm{g} / \mathrm{mL}$ and five had MIC of $32 \mu \mathrm{g} / \mathrm{mL}$. None of the $K$. pneumoniae was found to produce MBL by EDTA-meropenem disk approximation test. ${ }^{[18]}$

As per a study conducted by Castenheira et al,among 271 Klebsiella spp., carbapenemase encoding genes were observed in $62(22.9 \%)$ strains. Strains carrying KPC genes displayed MIC results against all carbapenems at $\geq 4$ $\mu \mathrm{g} / \mathrm{ml}$, whereas strains carrying blaVIM-and blaOXA-48-like had MIC values from $\leq 0.12$ to $>8 \mu \mathrm{g} / \mathrm{ml}$ for different 
carbapenem compounds. ${ }^{[20]}$ According to Endimiani A et al among carbapenems, $\mathrm{MIC}_{50 / 90} \mathrm{~s}$ were $4 / 64 \mathrm{mg} / \mathrm{L}$ for imipenem and meropenem, $4 / 32 \mathrm{mg} / \mathrm{L}$. Genetic analysis revealed that the isolates possessed the following bla genes: $b l a_{\mathrm{KPC}-2}(59.5 \%)$, bla $a_{\mathrm{KPC}-3}(40.5 \%)$, bla $a_{\mathrm{TEM}-1}(90.5 \%)$, bla $a_{\mathrm{SHV}-11}(95.2 \%)$ and bla $_{\mathrm{SHV}-12}(50.0 \%)$. PFGE demonstrated that $32(76.2 \%)$ isolates were clonally related (type A KPC). ${ }^{[21]}$ Also Spyros Pournaras et al investigated Meropenem heteroresistance in six apparently meropenem-susceptible, Klebsiella pneumoniae carbapenemase (KPC)-producing K. pneumoniae (KPC-KP) clinical isolates, compared with that in carbapenemasenegative, meropenem-susceptible controls. In population analyses, the KPC-KP isolates grew at meropenem concentrations of 64 to $256 \mu \mathrm{g} / \mathrm{ml}$. Heteroresistant colonies had significantly elevated expression of the $b l a_{\mathrm{KPC}}$ gene compared with the native populations. ${ }^{[22]}$

\section{Conclusion:-}

All the Klebsiella pneumoniae resistant isolates by vitek 2 were also having MIC in resistant range by BMD method and isolates positive for blaKPC gene are having higher MIC ranges, as all resistant isolates were having MIC $\geq 32 \mu \mathrm{g} / \mathrm{ml}$.

\section{References:-}

1. Fidelis E,Patricia C, Mark P B,Chad C and David R W .Comparison of Clinical \& Laboratory Standards Institute standards in antimicrobial susceptibility among the carbapenemase producing Enterobacteriaceae.Future Sci. OA (2017) 3(4), FSO245.

2. Nordmann P and Poirel L. Emerging carbapenemases in Gram-negative aerobes. ClinMicrobiol Infect,2002 $8(6), 321-331$.

3. Anne Marie Q, Karen B.Carbapenemases; the versatile beta lactamases.Clin.Microbiol. Rev. 2007( 20)3, 440458.

4. Paterson DL, Bonomo RA. Extended-spectrum beta-lactamases: a clinical update. Clinical Microbiology Reviews.2005; 18:657-686.

5. Miriagou V, Tzouvelekis LS, Rossiter S, Tzelepi E, Angulo FJ, Whichard JM et al. Imipenem resistance in a Salmonella clinical strain due to plasmid-mediated class A carbapenemase KPC-2.Antimicrob.Agents Chemother.47:1297-1300.

6. Woodford N, Tierno PM, Young JK, Tysall L, Palepou MF, Ward E et al. Outbreak of Klebsiella pneumoniae producing a new carbapenem-hydrolyzing class A lactamase, KPC-3, in a New York medical center. Antimicrob.Agents Chemother.48:4793-4799.

7. Yigit H,Queenan AM,Rasheed JK,Biddle JW,Domenech-Sanchez A,Alberti S et al.Carbapenem-resistant strain of Klebsiella oxytoca harbouring carbapenem-hydrolyzing lactamase KPC-2.Antimicrob.Agents Chemother.47:3881-3889.

8. Anderson KF,Lonsway DR,Rasheed JK,Biddle J,Jensen B,McDougal LK et al .Evaluation of methods to identify the Klebsiella pneumoniae carbapenemase in Enterobacteriaceae.Journal of Clinical Microbiology, Aug,2007,2723-2725.

9. Mayer G. Antibiotics - protein synthesis, nucleic acid synthesis, and metabolism. In: Microbiol. Immunol. Hunt RC (Ed.). University of South Carolina, SC, USA (2016). http://www.microbiologybook.org/mayer/antibiot.htm.

10. Sievert DM, Ricks P, Edwards JR et al. Antimicrobial-resistant pathogens associated with healthcare-associated infections: summary of data reported to the National Healthcare Safety Network at the Centers for Disease Control and Prevention, 2009-2010. Infect. Control Hosp. Epidemiol.2013; 34(1), 1-14.

11. Gupta N, Limbago BM, Patel JB, Kallen AJ. Carbapenem-resistant Enterobacteriaceae: Epidemiology and prevention. Clin. Infect.Dis. 2011; 53(1), 60-67.

12. Clinical and Laboratory Standards Institute (CLSI). Performance standards for antimicrobial susceptibility testing. 22nd informational supplement (M100-S22). Wayne, PA: CLSI; 2012.

13. Clinical and Laboratory Standards Institute (CLSI). Performance standards for antimicrobial susceptibility testing. 24nd informational supplement (M100-S24). Wayne, PA: CLSI; 2014.

14. Schechner V, Straus-Robinson K,Schwartz D,Pfeffer I,Tarabeia J,Moskovich R et al .Evaluation of PCRbased testing for surveillance of KPC-producing Carbapenem resistant members of the Enterobacteriaceae family. Journal of Clinical Microbiology.Oct 2009;47(10):3261-3265.

15. Marquez P,Terashita D, Dassey D, Mascola L.Population-based incidence of carbapenem-resistant Klebsiella pneumoniae along the continuum of care, Los Angeles County. Infect Control Hosp Epidemiol. 2013 $\mathrm{Feb} ; 34(2): 144-50$. 
16. Shanmugam P, Meenakshisundaram J,Jayaraman P.blaKPC gene Detection in Clinical Isolates of Carbapenem Resistant Enterobacteriaceae in a Tertiary Care Hospital.J Clin Diagn Res. 2013 Dec;7(12):2736-8.

17. Seibert G,Hörner R,Meneghetti BH, Righi RA ,Frasson NA ,Forno D et al .Nosocomial infections by Klebsiella pneumoniae carbapenemase producing enterobacteria in a teaching hospital Einstein (São Paulo). International Journal of Basic and Applied Medical Sciences .2014;12(3):282-6.

18. Parveen RM,Harish BN, Parija SC.Emerging Carbapenem Resistance Among Nosocomial Isolates Of Klebsiella Pneumoniae in South india.International Journal of Pharma and Bio Sciences V1(2)2010.

19. Giani T, Pini B, Arena F, Conte V, Bracco S, Migliavacca R et al .Epidemic diffusion of KPC carbapenemase producing Klebsiella pneumoniae in Italy results of the first country wide survey $15^{\text {th }}$ may to $30^{\text {th }}$ june 2011.Euro Surveill.2013;18(22).

20. Castenheira, Woosley LN,Mendes RE,Sader HS,Jones RN .Epidemiologic Detection of Carbapenemaseproducing Klebsiella spp. by EUCAST or CLSI Clinical Breakpoints ICAAC 2009. JMI Laboratories North Liberty, IA, USA.

21. Endimiani A,Hujer AM, Perez F, Bethel CR, M. Hujer KM, Kroeger J et al.Characterization of blaKPC containing Klebsiella pneumoniae isolates detected in different institutions in the Eastern USA. J Antimicrob Chemother. 2009 Mar; 63(3): 427-437.

22. Pournaras S, Kristo I, Vrioni G, Ikonomidis A, Poulou A, Petropoulou D,et al .Characteristics of Meropenem Heteroresistance in Klebsiella pneumoniae Carbapenemase (KPC)-Producing Clinical Isolates of $K$. pneumoniae.J. Clin. Microbiol. 2010; 48 (7) 2601-2604. 